Olvera-Vargas, M., Figueroa-Rangel, B. L., \& Solís Robles, C. (2021). Floristic composition, structure and environmental characterization of Cyathea costaricensis population in a remnant cloud forest in Mexico. Revista de Biología Tropical, 69(3), 1079-1097. https://doi.org/10.15517/rbt. v69i3.47359

https://doi.org/10.15517/rbt.v69i3.47359

\title{
Floristic composition, structure and environmental characterization of Cyathea costaricensis population in a remnant cloud forest in Mexico
}

\author{
Miguel Olvera-Vargas ${ }^{1 *}$; (D) https://orcid.org/0000-0002-7290-1639 \\ Blanca L. Figueroa-Rangel ${ }^{1}$; (iD https://orcid.org/0000-0002-5869-5277 \\ Christiam Solís Robles²; (D https://orcid.org/0000-0002-1341-1605
}

1. Departamento de Ecología y Recursos Naturales, Centro Universitario de la Costa Sur, Universidad de Guadalajara, Av. Independencia Nacional \# 151. Autlán de Navarro, Jalisco, México; molvera@cucsur.udg.mx (*Correspondence), bfrangel@cucsur.udg.mx

2. Centro Universitario de la Costa Sur, Universidad de Guadalajara, Av. Independencia Nacional \# 151, Autlán de Navarro, Jalisco, México; sorch94@gmail.com

Received 10-VI-2021. Corrected 26-VIII-2021. Accepted 17-IX-2021.

\begin{abstract}
Introduction: Tree ferns are significant components of temperate, tropical and subtropical forests, contributing to shape complex forest stand structures.

Objectives: 1) to describe the population structure of Cyathea costaricensis in a remnant cloud forest of Westcentral Mexico; 2) to characterize and relate the floristic composition and the structure of the most important tree species associated to the $C$. costaricensis population and; 3 ) to describe the environment where $C$. costaricensis occurs.

Methods: We estimated the Importance Value Index (IVI) to select the most important canopy-dominant species associated to C. costaricensis; we constructed height and Diameter at Breast Height (DBH) frequency distributions for those selected species according to IVI as well as for C. costaricensis population; we computed the asymmetry of the frequency distributions through the coefficient of skewness and the probability density function via the Kernel density estimation. We tested for differences between canopy-dominant tree species and $C$. costaricensis population structure by the non-parametric Wilcoxon rank sum test.

Results: C. costaricensis individuals presented the smallest heights and intermediate DBH sizes as compared with the canopy-dominant species, with statistically significant differences for height but not for DBH according to the Wilcoxon test. Most of the tree fern individuals were located in uneven terrains and over the base slope of the terrain; canopy openness and Total Radiation Under the Canopy values were similar to those reported for Cyathea species elsewhere.

Conclusions: We confirm the hypothesis of comparable structure between the canopy-dominant species and the C. costaricensis population only for $\mathrm{DBH}$; on the contrary, for trunk height, there were statistically significant differences; the small heights of $C$. costaricensis suggest their coexistence in the understory through sheltering from the taller canopy-dominants. Mostly all individuals of $C$. costaricensis were confined to local environmental conditions, particularly to physiography.
\end{abstract}

Key words: tree ferns; population structure; canopy species composition; reversed $J$-shaped; height categories; local environment. 
Tree ferns in some forest communities are important elements in the development of complex forest structure over time (Fedrigo et al., 2019). They inhabit a variety of forest ecosystems as prominent components of temperate and tropical understories, contributing significantly to the total basal area and stem density (Bystriakova et al., 2011; Shepherd et al., 2019). Several tree ferns: Alsophila tricolor (Colenso) R. Tryon, A. engelii R.M. Tryon, Cyathea caracasana (Klotzsch) Domin are known to be negatively stand density dependent; such negative density dependence and strong environmental filtering, may affect the establishment of tree fern seedlings and saplings, particularly when they occur near conspecific adult tree ferns (Brock et al., 2020; Chacón-Labella et al., 2014).

In preserved areas, combined with understory shade, some tree fern species (Cyathea caracasana) can enter a "persistence mode" until a canopy gap opens above them; subsequently, they begin a rapid growth, producing spores and seedling recruitment (Arens, 2001). The recruitment of tree ferns may be controlled by environmental filters, including forest canopy disturbances that create gaps and edges, which in turns modify local niche conditions (Bernabe et al., 1999; Brock et al., 2018a). Sun-light, temperature, humidity, small-scale physiographic variations, are among the most important environmental determinants for their occurrence (Mendoza-Ruiz \& Ceja-Romero, 2014). Many tree fern species thrive well along stream banks, soils rich in organic matter and over more exposed sites with direct sunlight; others like Cyathea sinuata Hook. \& Grev. (synonymous of Alsophila sinuata) succeed well even on rocky stream side banks (Ranil et al., 2017).

Tree ferns facilitate regeneration of certain species (Gaxiola et al., 2008); hence they have an important influence on the regeneration niche of potentially dominant tree species through macro-litter fall and shading with effects on nutrient cycling. A number of tree ferns species are recognized as keystone species for their role in casting deep shade on forest floor environment, acting as a differential ecological filter on regeneration processes (Forbes et al., 2016). The ecological relevance of tree ferns has been documented in several regions of the world, particularly in the understory as crucial factors determining forest structure, through the release of shade-intolerant conifers from angiosperm competition (Brock et al., 2020). But also, tree ferns can affect successional processes around their neighborhood by inhibiting the growth of understory species through the release of allelochemicals (Negrão et al., 2017), in some cases, inhibiting and slowing forest succession (Brock et al., 2018b). Tree ferns are important components of cloud forests in Mexico (Hernández-Álvarez et al., 2019; Ruiz Coyoahua, 2020), however, ecological information on these vascular plants has been largely restricted to taxonomic descriptions (Mendoza-Ruiz \& Ceja-Romero, 2014) and to assess species richness (Ramírez-Barahona et al., 2011). Cloud forest is a community included in the humid forest ecosystems of Mexico, mostly located between 1000 to 3000 m.a.s.l. (Villaseñor, 2010) where high humidity, due to cloud condensation, is common. In Mexico, one of the most important tree fern genera is Cyathea; it contains approximately 10 species under different conservation categories, mostly growing in sub-tropical, tropical and cloud forests (Ruiz Coyoahua, 2020). One of these tree fern species is Cyathea costaricensis (Mett. ex Kuhn) Domin, a Mesoamerican endemic species distributed from Western Mexico to Western Panama (Mickel \& Smith, 2004); although it is tagged as an Endangered species according to the Mexican Red List NOM-059-SEMARNAT-2010 (Secretaría del Medio Ambiente y Recursos Naturales, 2010), there is no documented studies on its ecology. Accordingly, this study seeks to answer: how tree ferns coexist with the canopy-dominant shade-tolerant species of a remnant cloud forest in West-Central Mexico? Therefore, the objectives in the present study were: 1) to describe the population structure of $C$. costaricensis in a remnant cloud forest of West-Central Mexico; we hypothesized that $C$. costaricensis is an 
important element beneath the canopy of dominant trees with a typical behavior of a shadetolerant species, thus its diameter and height frequency distribution will be characterized by a reversed $J$-shape showing a gradual lessening of individuals as its diameter and height category increase; 2) to characterize and relate the canopy floristic composition including the structure of the most important tree species, to $C$. costaricensis population structure; we hypothesized that the canopy-dominant species and the $C$. costaricensis population, will show a similar structural pattern due to their shadetolerance behavior; 3) to describe the environment where $C$. costaricensis occurs, we expect that sun-light related variables should explain the presence of this species in our study area.

\section{MATERIALS AND METHODS}

Study site: We carried out this research in a remnant cloud forest which contains a unique ancient flora of Pleistocene origin, mainly dominated by Acer binzayedii Y.L. Vargas-Rodr., Podocarpus reichei J. Buchholz \& N.E. Gray and Abies religiosa (Kunth) Schltdl. \& Cham. (Del Castillo-Batista et al., 2018; Vargas-Rodríguez et al., 2012). The study area is located over the East-Southeast zone in Talpa de Allende Jalisco, Mexico (between the coordinates $\left(20^{\circ} 13^{\prime} 46.28^{\prime \prime} \mathrm{N} \&\right.$ $\left.104^{\circ} 44^{\prime} 2.69^{\prime \prime} \mathrm{W}\right)$, at 1798 m.a.s.1.), within the tributary Talpa watershed. Annual average precipitation extends from 1600 to 1800 $\mathrm{mm}$ and temperature from 16 to $22{ }^{\circ} \mathrm{C}$. This floristic zone is characterized by a complex biogeographical history that combines Holarctic, Tropical, Pantropical and Asian-American elements as a result of the convergence of the Nearctic and the Neotropic biogeographical zones (Vázquez-García et al., 2000).

Data collection method: First, we conducted a field exploration on the whole area covered by the relict cloud forest in the study area where we observed Cyathea costaricensis individuals (around $3 \mathrm{ha}$ ); in a second stage, we census all individuals of Cyathea costaricensis present in the study area.

Vegetation characterization: Field-work explorations revealed that Cyathea costaricensis population in the study area has a fragmented and rather small population size. Therefore, we established seven circular plots $\left(500 \mathrm{~m}^{2}\right.$ each). In each plot, all C. costaricensis individuals were counted, identified and their total height and diameter at breast height (DBH; measured at $1.30 \mathrm{~m}$ height above the forest floor) were measured. Tree species $\geq 5 \mathrm{~cm}$ $\mathrm{DBH}$, co-occurring with $C$. costaricensis, were also recorded by species, DBH and height. When necessary, we removed any obstacle (e.g. lichens, dead material, creeper plants, etc.) that might impede an accurate DBH measurement. All individuals were identified during the fieldwork to species level according with the specimens deposited in the ZEA Herbarium of the Department of Ecology and Natural Resources of the Centro Universitario de la Costa Sur, University of Guadalajara; the scientific species names were cross-checked according to Tropicos.org database (Tropicos.org, 2021).

Environment characterization: In each plot, we recorded the following variables: elevation (m.a.s.1.); slope inclination (as a indicative of soil moisture and depth due to surface runoff) measured in the steepest down-slope of the terrain; aspect expressed as azimuth in degrees from 0 to $360^{\circ}$ and then transformed into a continuous variable according to Beers et al. (1966); topography, visually evaluated in two categories, even and uneven terrains (Table 1); stones and rocks (a visual evaluation of the amount of this material covering the surface of the plot; both assessed into five categories) and canopy strata (a visual assessment of the number of vertical strata formed by crown of the trees, evaluated in four categories) (Table 1). The environmental characterization was carried out following the criteria proposed by OlveraVargas et al. (1996). We also assessed the light environment using hemispherical photographs following the protocol proposed by Zhang et al. 
(2005). For this purpose, we took three hemispherical photographs within each $500 \mathrm{~m}^{2}$ plot, one at the upper slope, one at the middle and one at the lower. We used a Nikon Coolpix 990 digital camera and a Nikon Fish-eye Converter FC-E8 $0.21 \times$ lens attached to a self-leveling tripod mount. For hemispherical image analysis, we used WinSCANOPY (Regent Instruments Inc., 2005) considering the following variables: canopy openness (CO), canopy gap fraction (CGF), leaf area index (LAI), photosynthetic photon flux density (PPFDu), total radiation over the canopy (TROC), total radiation under the canopy (TRUC), direct radiation (DiR) and diffuse radiation (DfR) (Table 1). We recorded the date and the time of the day in which each photo was taken. We used this information as input during image analysis in WinSCANOPY.

Data analysis: Confidence intervals at 95 $\%$ were computed by plot for all quantitative environmental variables while the mode was computed for qualitative variables. Confidence intervals were also estimated for $\mathrm{DBH}$, height and basal area for Cyathea costaricensis and all canopy-dominant species. In order to establish the relative ecological importance of each species to the overall forest community dominance, we first calculated the Importance Value Index (IVI) (Etherington et al., 1987). This index represents the sum of relative density (number of individuals per species/total number of individuals all species), relative frequency (number of plots in which species appear/total number of plots) and relative basal area (total basal area per species/total basal area all species). To further describe the tree canopy-dominant species composition, we selected those species whose IVI were higher than $70 \%$. We first computed quartiles for height and DBH for the most important species and display them using box and whisker plots. We analyzed size frequency distributions for $C$. costaricensis and for the canopy-dominant species with the highest IVI. For DBH, we used histograms with 5 $\mathrm{cm}$ intervals. For height categories, we used the approach by Pérez-Paredes et al. (2014); these authors used the following categories in their study with Cyathea fulva (M. Martens \& Galeotti) Fée: Juveniles: individuals $<3 \mathrm{~m}$ height; Intermediate: individuals 3-7 m height; Mature: individuals $>7 \mathrm{~m}$ height; we decided to apply the same height categories since $C$. costaricensis and C. fulva have relatively similar growth in terms of maximum height of their stems. To further compare height class frequency distribution of $C$. costaricensis with height class frequency distribution of the species with the highest IVI, at plot level, we constructed histograms using the following height intervals (in meters): < 3, 3-7, 7-11, 11-15, 15-19, 19-24, $24-27,>27$. We also estimated total basal area by height class for $C$. costaricensis in order to discern the contribution in basal area by each height sizes. The coefficient of skewness $\left(\mathrm{g}_{1}\right)$ was computed for both height and DBH frequency distributions to assess symmetry. A $g_{1}$ $=0$ indicates a symmetric distribution. $\mathrm{A}_{1}<0$ indicates a negative asymmetry skewed to the left, while a $g_{1}>0$ indicates a positive asymmetry skewed to the right. We estimated the coefficient of skewness following the Wright et al. (2003) metric approach:

$$
g_{1}=\frac{n \sum_{t}\left(x_{i}-\bar{x}\right)^{3}}{(n-1)(n-2) s^{3}}
$$

Where: $n, x i, x$, and s represent the number of individuals, the logarithm of DBH or height for individual $i$, the mean of the $x i$, and the standard deviation (Std) of the $x i$, respectively.

In order to compare height and DBH sizes of $C$. costaricensis with the tree canopydominant species with the highest IVI, a kernel probability density function was computed and plotted, one for $C$. costaricensis and one for the canopy-dominant species with the highest IVI. The shape of the kernel probability density function does not rely on the number of class intervals subjectively chosen and it is built on the individuals' location of all data (Węglarczyk, 2018); those characteristics were suitable as we want to compare dissimilar sizes for height and DBH of $C$. costaricensis and its canopy-dominant species. Shapiro-Wilk normality test was applied to test the normality 
TABLE 1

Environmental variables recorded in the study plots with Cyathea costaricensis following Olvera-Vargas et al. (1996)

\begin{tabular}{|c|c|c|c|c|}
\hline Variable name & Acronym & $\begin{array}{c}\text { Acronym for } \\
\text { categorical } \\
\text { variables }\end{array}$ & $\begin{array}{l}\text { Measurement units } \\
\text { or names for } \\
\text { categorical variables }\end{array}$ & Variable Description \\
\hline 1. Elevation & Elev & & $\begin{array}{l}\text { Metres above sea } \\
\text { level }\end{array}$ & $\begin{array}{l}\text { Distance above sea level measured with } \\
\text { a Suunto altimeter. }\end{array}$ \\
\hline 2. Slope inclination & Slope & & Percentage & $\begin{array}{l}\text { Percentage of slope terrain inclination } \\
\text { measured in the steepest down-slope. }\end{array}$ \\
\hline 3. Aspect & Aspect & & Degrees & $\begin{array}{l}\text { Azimuth of dominant direction of } \\
\text { downward-facing slope-inclination. } \\
\text { Log-transformed into a continuous } \\
\text { variable. }\end{array}$ \\
\hline \multirow[t]{3}{*}{ 4. Topography } & \multirow[t]{3}{*}{ Top } & & & A measure of the terrain evenness. \\
\hline & & Top1 & Even terrain & $\begin{array}{l}\text { Continuous and homogeneous terrain } \\
\text { inclination. }\end{array}$ \\
\hline & & Top2 & Uneven terrain & $\begin{array}{l}\text { Discontinuous and heterogeneous } \\
\text { terrain inclination. }\end{array}$ \\
\hline \multirow[t]{5}{*}{ 5. Rocks } & \multirow[t]{5}{*}{ Rck } & Rck0 & Absence & \multirow{5}{*}{$\begin{array}{l}\text { Visual evaluation of the amount of rocks } \\
\text { covering the surface of the plot. }\end{array}$} \\
\hline & & Rck1 & Hardly visible & \\
\hline & & Rck2 & Scarce & \\
\hline & & Rck3 & Moderate & \\
\hline & & Rck4 & Abundant & \\
\hline \multirow[t]{5}{*}{ 6. Stones } & \multirow[t]{5}{*}{ Sto } & Sto0 & Absence & \multirow{5}{*}{$\begin{array}{l}\text { Visual evaluation of the amount of } \\
\text { stones covering the surface of the plot. }\end{array}$} \\
\hline & & Sto1 & Hardly visible & \\
\hline & & Sto2 & Scarce & \\
\hline & & Sto3 & Moderate & \\
\hline & & Sto4 & Abundant & \\
\hline \multirow[t]{4}{*}{ 7. Canopy strata } & \multirow[t]{4}{*}{ CStr } & CStr1 & One vertical stratum & \multirow{4}{*}{$\begin{array}{l}\text { Visual assessment of the number } \\
\text { of vertical strata formed by the tree } \\
\text { crowns. Shrubs were not considered for } \\
\text { this assessment. }\end{array}$} \\
\hline & & CStr2 & Two vertical strata & \\
\hline & & CStr3 & Three vertical strata & \\
\hline & & CStr4 & $\begin{array}{l}\text { No discernible } \\
\text { vertical stratums }\end{array}$ & \\
\hline 8. Canopy openness & \multicolumn{2}{|l|}{$\mathrm{CO}$} & \multicolumn{2}{|l|}{ Percentage } \\
\hline 9. Canopy gap fraction & \multicolumn{2}{|l|}{ CGF } & \multicolumn{2}{|l|}{ Percentage } \\
\hline 10. Leaf area index & \multicolumn{2}{|l|}{ LAI } & \multicolumn{2}{|l|}{$\left(\mathrm{m}^{2} \mathrm{~m}^{-2}\right)$} \\
\hline $\begin{array}{l}\text { 11. Photosynthetic photon } \\
\text { flux density under the } \\
\text { canopy }\end{array}$ & \multicolumn{2}{|l|}{ PPFDu } & \multicolumn{2}{|l|}{$\left(\mu \mathrm{mol} / \mathrm{s}-\mathrm{m}^{2}\right)$} \\
\hline $\begin{array}{l}\text { 12. Total radiation over the } \\
\text { canopy }\end{array}$ & \multicolumn{2}{|l|}{ TROC } & \multicolumn{2}{|l|}{$\left(\mathrm{MJ} / \mathrm{m}^{2}\right.$ day $)$} \\
\hline $\begin{array}{l}\text { 13. Total radiation under the } \\
\text { canopy }\end{array}$ & \multicolumn{2}{|l|}{ TRUC } & \multicolumn{2}{|l|}{$\left(\mathrm{MJ} / \mathrm{m}^{2}\right.$ day $)$} \\
\hline 14. Direct radiation & \multicolumn{2}{|l|}{ DiR } & \multicolumn{2}{|l|}{ Percentage } \\
\hline 15. Diffuse radiation & \multicolumn{2}{|l|}{ DfR } & \multicolumn{2}{|l|}{ Percentage } \\
\hline
\end{tabular}


of height and DBH class frequency distribution for C. costaricensis and for the canopydominant species with the highest IVI. To test for differences between the canopy-dominant species and the $C$. costaricensis population structure, using DBH and height as indicators of structural behavior, the non-parametric Wilcoxon rank sum test was estimated for DBH and height; the Wilcoxon test compares two independent groups when data are not normally distributed (MacFarland \& Yates, 2016). Descriptive statistics and hypothesis tests (Shapiro-Wilks and Wilcoxon) were estimated in $\mathrm{R}$ software-v.3.6 (R Core Team, 2018); for the coefficient of skewness, we used the e1071 library and for graphs, the ggplot2 library.

\section{RESULTS}

Floristic composition and structural characterization: We recorded a total of 333 individuals $\geq 5 \mathrm{~cm}$ of DBH distributed in 27 species, 24 genera and 24 families. Cyathea costaricensis was represented by 62 individuals, representing $18.61 \%$ of the total number of individuals, followed by Carpinus tropicalis (Donn. Sm.) Lundell (50 individuals), Podocarpus reichei (with 38), Clusia salvinii Donn. Sm (with 32), Conostegia volcanalis Standl. \& Steyerm. (with 23) and Acer binzayedii (with 23). In contrast, 18 species were present with fewer than ten individuals. Quercus (3 species) was the most diverse genus, followed by Eugenia (2 species). Considering those species with $\geq 3$ individuals, Acer binzayedii Y.L. Vargas-Rodr. was the species with the biggest DBH and Eugenia crenularis Lundell with the smallest DBH; the tallest species corresponded to Quercus uxoris McVaugh and the smallest height to Cyathea costaricensis (Table 2).

IVI results revealed that 10 species, out of the 27 recorded in the study plots, contributed with $>70 \%$ to the total dominance in the community; Cyathea costaricensis showed the second higher IVI value $(127 \%)$ only after Carpinus tropicalis (135 \%); A. binzayedii and $P$. reichei attained similar IVI's (around $118 \%$ ); these dominant species were followed by Quercus nixoniana S. Valencia \& LozadaPérez (100 \%), Clusia salvinii (99\%), Conostegia volcanalis (95\%), Clethra fragrans L.M. González \& R. Delgad. (93 \%), Quercus uxoris $(83 \%)$ and Ilex brandegeeana (75\%). The remaining of the species reported IVI's with less than $50 \%$ (Fig. 1).

Cyathea costaricensis, Carpinus tropicalis and Podocarpus reichei were the most frequent species, recorded in the seven plots, while 11 species with frequencies around $14 \%$ were present in only one plot. The same three species with the highest relative frequency, were also the most abundant. Acer binzayedii (around $26 \%)$ and Carpinus tropicalis (21\%) were the most dominant species according to their relative basal area, while 21 species contributed with less than $5 \%$ (Fig. 1). Trunk height was variable among the ten species with the highest IVI. Cyathea costaricensis showed the smallest mean height, even smaller than those shade-tolerant species commonly found in the understory in our study area such as Clusia salvinii and Conostegia volcanalis; the largest mean heights were reported for Quercus uxoris and Acer binzayedii; this last species also showed the tallest individuals, with tree heights up to $40 \mathrm{~m}$. In terms of stem height, Carpinus tropicalis and Quercus nixoniana showed the greatest variation (Fig. 2A, Table 2). In terms of $\mathrm{DBH}, C$. costaricensis displayed an intermediate mean size when compared with the rest of the species; highest values for DBH corresponded to A. binzayedii, $Q$. uxoris, $C$. tropicalis and $Q$. nixoniana in that order of magnitude; the highest $\mathrm{DBH}$ variation corresponded to $A$. binzayedii and the lowest variation to $C$. costaricensis (Fig. 2B, Table 2).

Structural variation by plot: The number of individuals for $C$. costaricensis varied among plots, with plot 2 showing the highest number of individuals $(\mathrm{N}=18)$, followed by plot $5(\mathrm{~N}=12)$, whilst the lowest number $(\mathrm{N}=$ 4) was present in plots 1 and 4; the smallest mean for $\mathrm{DBH}$, height and basal area corresponded to plot 2 and the highest to plot 6 (Table 3). 
TABLE 2

List of species present in the remnant cloud forest in west-central Mexico

\begin{tabular}{|c|c|c|c|c|c|c|}
\hline Species & Family & Acronym & $\mathrm{N}$ & $\mathrm{DBH}$ & $\mathrm{Ht}$ & $\mathrm{BA}$ \\
\hline $\begin{array}{l}\text { Cyathea costaricensis (Met. ex } \\
\text { Kuhn) Domin }\end{array}$ & Cyatheaceae & Cycos & 62 & $11.32 \pm 0.96$ & $6.01 \pm 0.48$ & $0.03 \pm 0.004$ \\
\hline $\begin{array}{l}\text { Carpinus tropicalis (Donn. Sm) } \\
\text { Lundell }\end{array}$ & Betulaceae & Catro & 50 & $17.76 \pm 3.14$ & $13.81 \pm 2.28$ & $0.09 \pm 0.03$ \\
\hline $\begin{array}{l}\text { Podocarpus reichei J. Buchholz } \\
\& \text { N.E. Gray }\end{array}$ & Podocarpaceae & Porei & 38 & $11.20 \pm 2.74$ & $9.09 \pm 1.90$ & $0.04 \pm 0.02$ \\
\hline Clusia salvinii Donn. Sm. & Clusiaceae & Clsal & 32 & $10.45 \pm 1.95$ & $7.21 \pm 0.90$ & $0.03 \pm 0.01$ \\
\hline $\begin{array}{l}\text { Acer binzayedii Y.L.Vargas- } \\
\text { Rodr. }\end{array}$ & Sapindaceae & Acbin & 23 & $25.03 \pm 10.27$ & $15.28 \pm 4.30$ & $0.26 \pm 0.20$ \\
\hline $\begin{array}{l}\text { Conostegia volcanalis Sandl. \& } \\
\text { Steyerm. }\end{array}$ & Melastomataceae & Covol & 23 & $9.05 \pm 1.69$ & $7.28 \pm 1.39$ & $0.021 \pm 0.008$ \\
\hline $\begin{array}{l}\text { Quercus nixoniana } \mathrm{S} \text {. Valencia } \\
\text { \& Lozada-Pérez }\end{array}$ & Fagaceae & Qunix & 19 & $17.11 \pm 6.70$ & $15.00 \pm 4.55$ & $0.10 \pm 0.07$ \\
\hline $\begin{array}{l}\text { Clethra fragrans L.M. González } \\
\text { \& R. Delgad. }\end{array}$ & Clethraceae & Clfra & 16 & $10.87 \pm 2.40$ & $9.88 \pm 2.60$ & $0.03 \pm 0.01$ \\
\hline Quercus uxoris McVaugh & Fagaceae & Quuxo & 13 & $20.68 \pm 8.87$ & $15.69 \pm 5.43$ & $0.14 \pm 0.11$ \\
\hline Zinowiewia concinna Lundell & Celastraceae & Zicon & 9 & $9.04 \pm 2.23$ & $9.33 \pm 3.28$ & $0.02 \pm 0.009$ \\
\hline Ilex brandegeeana Loes. & Aquifoliaceae & Ilbra & 7 & $10.62 \pm 7.40$ & $9.21 \pm 5.16$ & $0.03 \pm 0.04$ \\
\hline Eugenia crenularis Lundell & Myrtaceae & Eucre & 6 & $8.26 \pm 3.41$ & $9.00 \pm 4.19$ & $0.017 \pm 0.013$ \\
\hline Juglans major (Torr.) A.Heller & Juglandaceae & Jumaj & 6 & $15.05 \pm 6.91$ & $13.00 \pm 9.29$ & $0.05 \pm 0.05$ \\
\hline Inga laurina (Sw.) Willd. & Fabaceae & Inlau & 5 & $12.08 \pm 6.58$ & $11.3 \pm 5.61$ & $0.037 \pm 0.04$ \\
\hline Magnolia pacifica A. Vázquez & Magnoliaceae & Mapac & 3 & $13.5 \pm 6.57$ & $13.33 \pm 15.17$ & $0.04 \pm 0.04$ \\
\hline $\begin{array}{l}\text { Prunus cortapico Kerber ex } \\
\text { Koehne }\end{array}$ & Rosaceae & Prcor & 3 & $13.76 \pm 11.28$ & $12.33 \pm 6.23$ & $0.05 \pm 0.17$ \\
\hline Quercus laurina Bonpl. & Fagaceae & Qulau & 3 & $9.36 \pm 1.0$ & $7.33 \pm 3.79$ & $0.019 \pm 0.004$ \\
\hline $\begin{array}{l}\text { Dendropanax arboreus (L) } \\
\text { Decne. \& Planch. }\end{array}$ & Araliaceae & Dearb & 2 & $*$ & $*$ & $*$ \\
\hline $\begin{array}{l}\text { Myrsine coriacea (Sw.) R. Br. } \\
\text { ex Roem. \& Schult. }\end{array}$ & Myrtaceae & Mycor & 2 & $*$ & $*$ & $*$ \\
\hline Perrottetia longistylis Rose & Dipentodontaceae & Pelon & 2 & $*$ & $*$ & $*$ \\
\hline Saurauia serrata DC. & Actinidiace & Saser & 2 & $*$ & $*$ & $*$ \\
\hline $\begin{array}{l}\text { Symplocos citrea Lex. Ex La } \\
\text { Llave \& Lex }\end{array}$ & Symplocaceae & Sycit & 2 & $*$ & $*$ & $*$ \\
\hline Cordia prunifolia I.M. Johnst. & Boranginaceae & Copru & 1 & $*$ & $*$ & $*$ \\
\hline Eugenia culminicola McVaugh & Myrtaceae & Eucul & 1 & $*$ & $*$ & $*$ \\
\hline Persea hintonii C.K. Allen & Lauraceae & Pehin & 1 & $*$ & $*$ & $*$ \\
\hline Pinus herrerae Martínez & Pinaceae & Piher & 1 & $*$ & $*$ & $*$ \\
\hline Styrax radians P.W. Fritsch & Styracaceae & Strad & 1 & $*$ & $*$ & $*$ \\
\hline
\end{tabular}

$\mathrm{N}=$ Total number of individuals; $\mathrm{DBH}=$ Mean diameter at breast height $(\mathrm{cm}) ; \mathrm{Ht}=$ Mean tree height $(\mathrm{m}.) ; \mathrm{BA}=\mathrm{Mean}$ Basal Area $\left(\mathrm{m}^{2} / \mathrm{ha}\right)$. Confidence intervals $(95 \%)$ for DBH, Ht and BA. *Parameter estimation confidence intervals were not computed as only two individuals were present. 


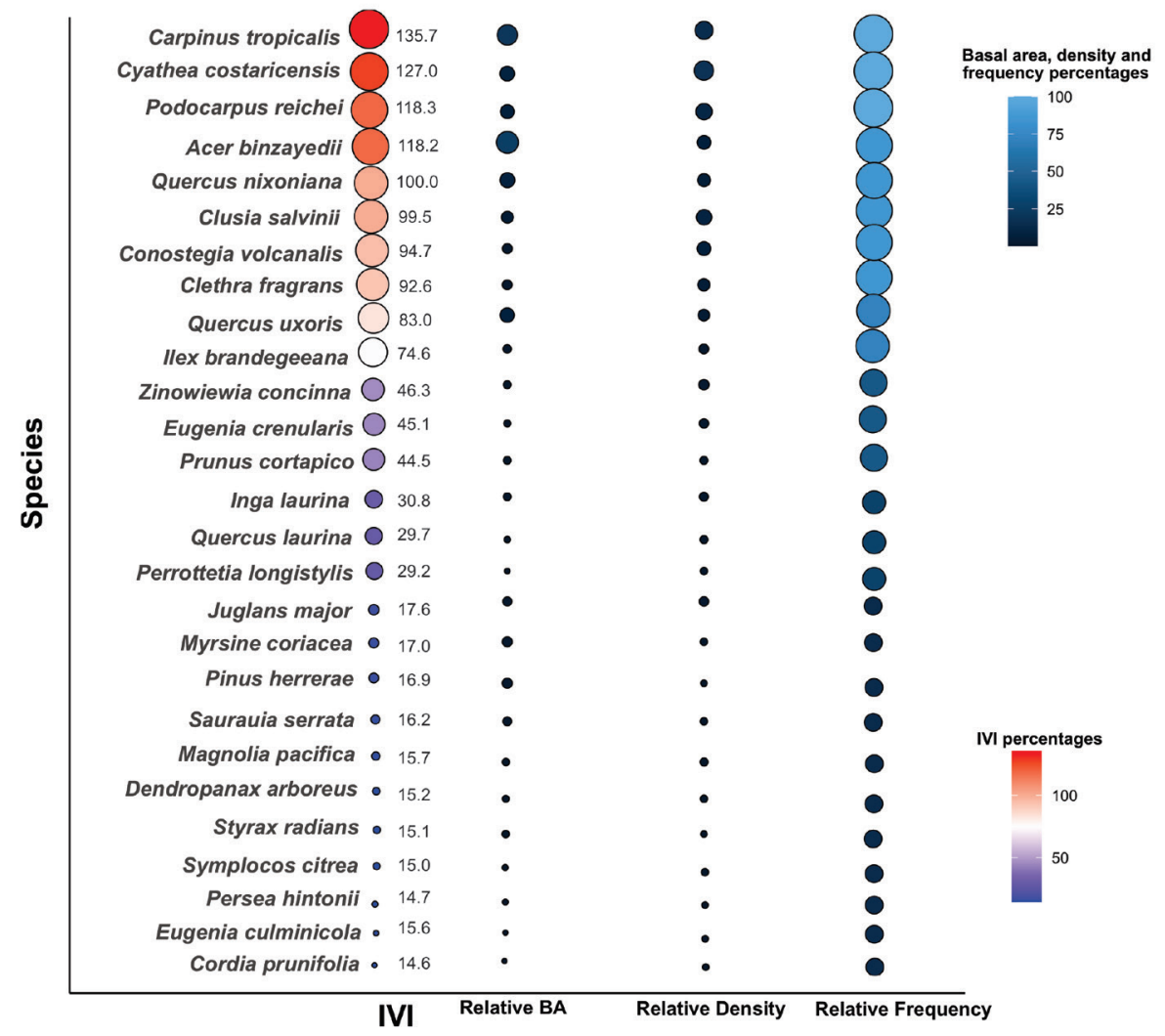

Fig. 1. Importance Index Value (IVI) of the species present in the remnant cloud forest in West-central Mexico. Percentage values are displayed in descending order for IVI, Relative Basal Area (BA), Relative Density and Relative Frequency.

Height class frequency distribution presented an unbalanced pattern at plot level. The coefficient of skewness, $g 1$ was $>0$ in all plots, revealing a positive asymmetry; their values were near to 1.0 in five $(1,2,3,6$ and 7$)$ of the seven plots exhibiting very irregular patterns in their distributions; on the contrary, plots 4 and 5 with higher $g 1$ values; the 2 words have to be separated (2.75 and 2.35 respectively), showed a reversed $J$-shaped with individuals mainly concentrated over the smallest height classes (between 7 to $11 \mathrm{~m}$ height) (Fig. 3). The highest number of $C$. costaricensis individuals were in the intermediate height category in all plots, while only plots 2 and 3 showed individuals in the three height categories (mature, intermediate and juveniles). The tallest individuals corresponded to A. binzayedii, Carpinus tropicalis, Quercus uxoris and Q. nixoniana in all plots, while Clusia salvinii and Conostegia volcanalis were also recurrent with small values in height (Fig. 3).

DBH class frequency distribution was moderately characterized by the classic $J$-shaped in plots 2, 4 and 5; this represents a large number of small- to middle diameter size classes of intermediate to shade tolerant species. The coefficient of skewness $(g 1)$ revealed that all the studied plots showed positive asymmetry, reinforcing that individual over smaller DBH classes dominated the plots (Fig. 4).

Most of the species contained individuals in 10,15 and $20 \mathrm{~cm}$ DBH classes; C. costaricensis individuals were also concentrated in these DBH classes in the seven plots. Only few old-growth trees (corresponding to A. binzayedii, C. tropicalis, $Q$. uxoris and $Q$. nixoniana) were recorded with diameters higher than 40 


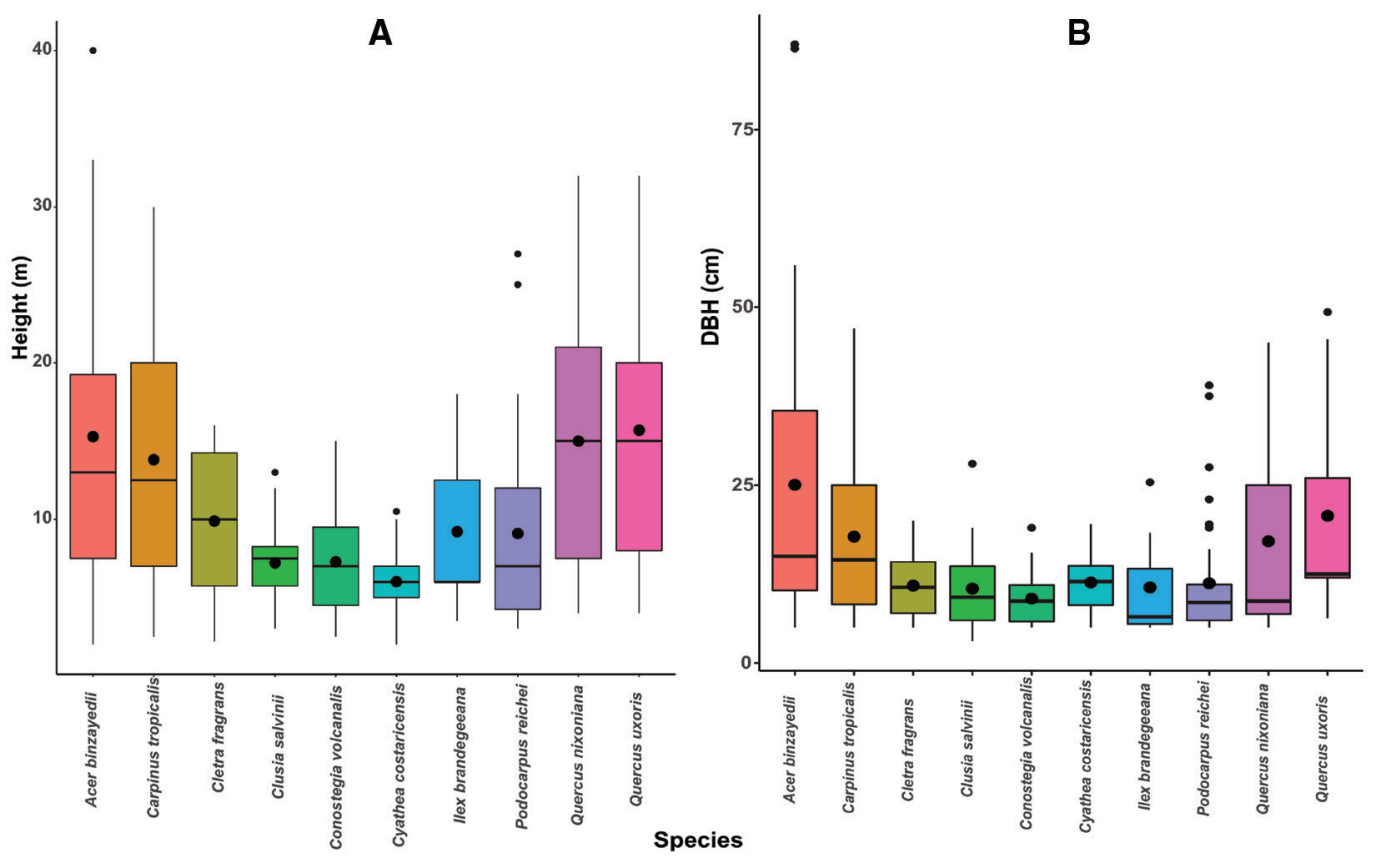

Fig. 2. Box and whisker plots representing quartiles for A. Height and B. DBH of the species with Importance Index Values $>70 \%$.

TABLE 3

Structural variables for Cyathea costaricensis by plot in the remnant cloud forest, West-central Mexico

\begin{tabular}{ccccc}
\hline Plot & Number of individuals & Mean DBH $(\mathrm{cm})$ & Mean Height $(\mathrm{m})$ & Mean Basal Area $\left(\mathrm{m}^{2} / \mathrm{plot}\right)$ \\
\hline 1 & 4 & 12.4 & 6.5 & 0.013 \\
2 & 18 & 8.7 & 4.7 & 0.006 \\
3 & 8 & 10.0 & 5.6 & 0.009 \\
4 & 4 & 12.1 & 6.1 & 0.012 \\
5 & 12 & 13.5 & 6.9 & 0.014 \\
6 & 9 & 13.6 & 7.1 & 0.015 \\
7 & 7 & 11.6 & 6.3 & 0.011 \\
CI & $8.8 \pm 3.64$ & $11.32 \pm 0.96$ & $6.01 \pm 0.48$ & $0.011 \pm 0.001$ \\
\hline
\end{tabular}

$\mathrm{CI}=$ confidence intervals at $95 \%$.

$\mathrm{cm}$. In certain plots, some of the species with the highest IVI, were represented in all DBH categories; for instance, $A$. binzayedii and Carpinus tropicalis in plot $1, Q$. uxoris and Clethra fragrans in plot 3, Clusia salvinii in plot 5 (Fig. 4).

Structural comparison of Cyathea costaricensis with canopy dominant species: Heights for C. costaricensis ranged from 2.0 to
$10.5 \mathrm{~m}$ with marked differences in number of individuals by height class. The intermediate class reported the highest number of individuals $(\mathrm{N}=43)$, followed by the mature class $(\mathrm{N}=$ $15)$ and the juvenile class $(\mathrm{N}=4)$. The highest contribution in basal area $\left(1.060 \mathrm{~m}^{2}\right)$ was estimated for the intermediate class (Fig. 5A). The coefficient of asymmetry $(g 1)$ was very close to zero $(g 1=0.06)$ representing a symmetric distribution; however, results from the Shapiro-Wilk 


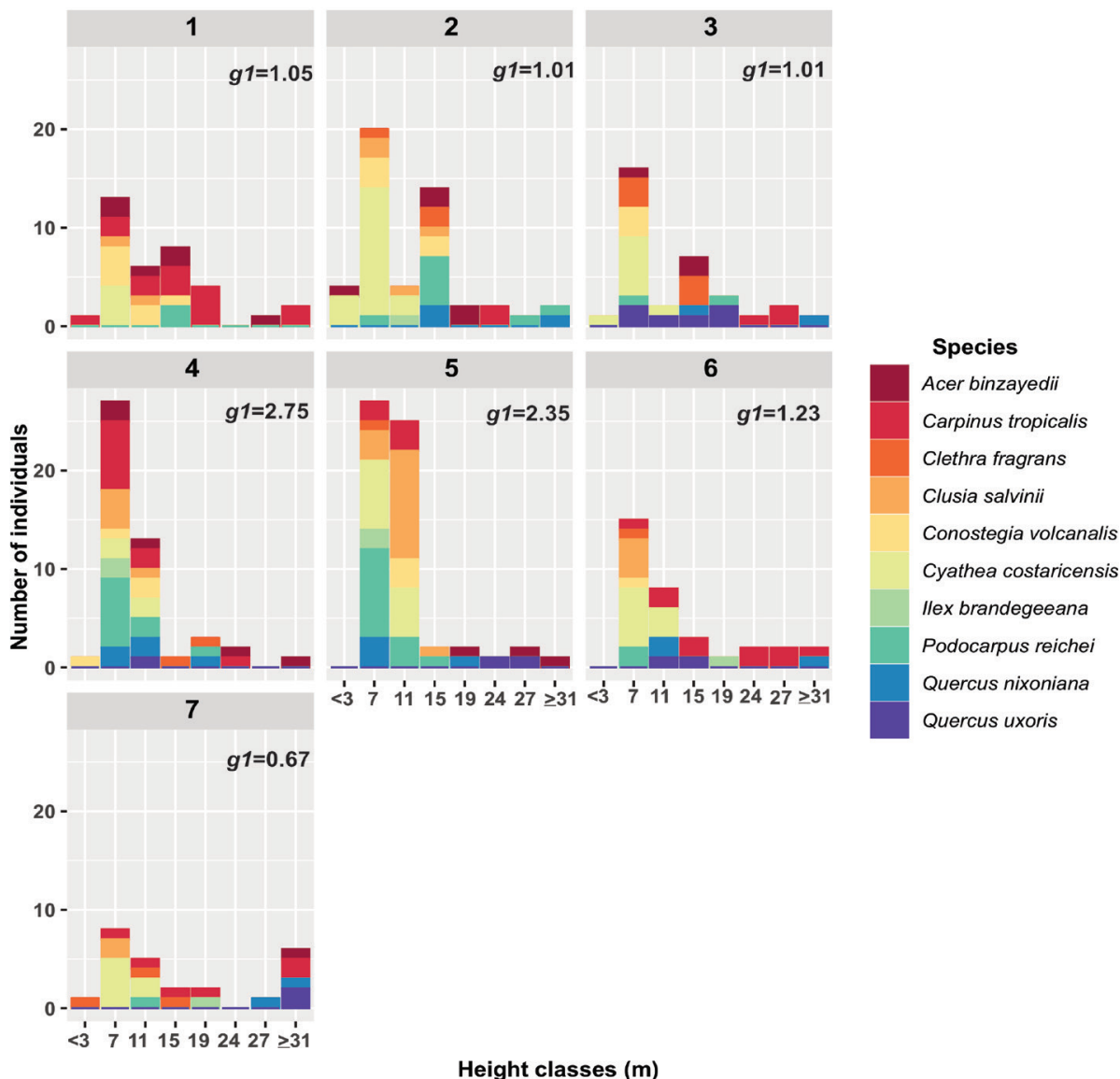

Fig. 3. Height class frequency distribution by plot considering the ten species with Importance Index Values $>70 \%$. $g 1=$ coefficient of skewness.

normality test revealed that height was not normally distributed $(\mathrm{P}<0.0001)$.

Regarding frequency distribution for the canopy-dominant species, the Shapiro-Wilk normality test revealed that height was not normally distributed $(\mathrm{P}<0.0001)$ as well.

A key difference emerged between the kernel probability density function of $C$. costaricensis population (around 0.25 ) and the canopy-dominant species with the highest IVI $(<0.10)$; in both cases, the highest probability was detected for heights $<10 \mathrm{~m}$ (Fig. 5B). The results of the Wilcoxon rank sum test showed statistically significant differences in height between $C$. costaricensis population and the canopy-dominant species $(\mathrm{W}=10018$, $\mathrm{P}<0.0001)$.

Concerning DBH, C. costaricensis ranged from 5 to $19.5 \mathrm{~cm}$, consequently it was only distributed in the first 4 classes $(5,10,15$ and $20 \mathrm{~cm}$ ) of the eight reported for the rest of the canopy-dominant species; even that coefficient of skewness was negative $(g 1=-0.176)$ suggesting a negative asymmetry with most individuals in the $15 \mathrm{~cm}$ class, its value proximate to zero also indicates symmetry in the distribution which is representative of a normal distribution (Fig. 5C); results which were corroborated with the Shapiro-Wilk normality test for DBH $(\mathrm{P}=0.1335)$. For the canopy-dominant species, the Shapiro-Wilk normality test revealed that 


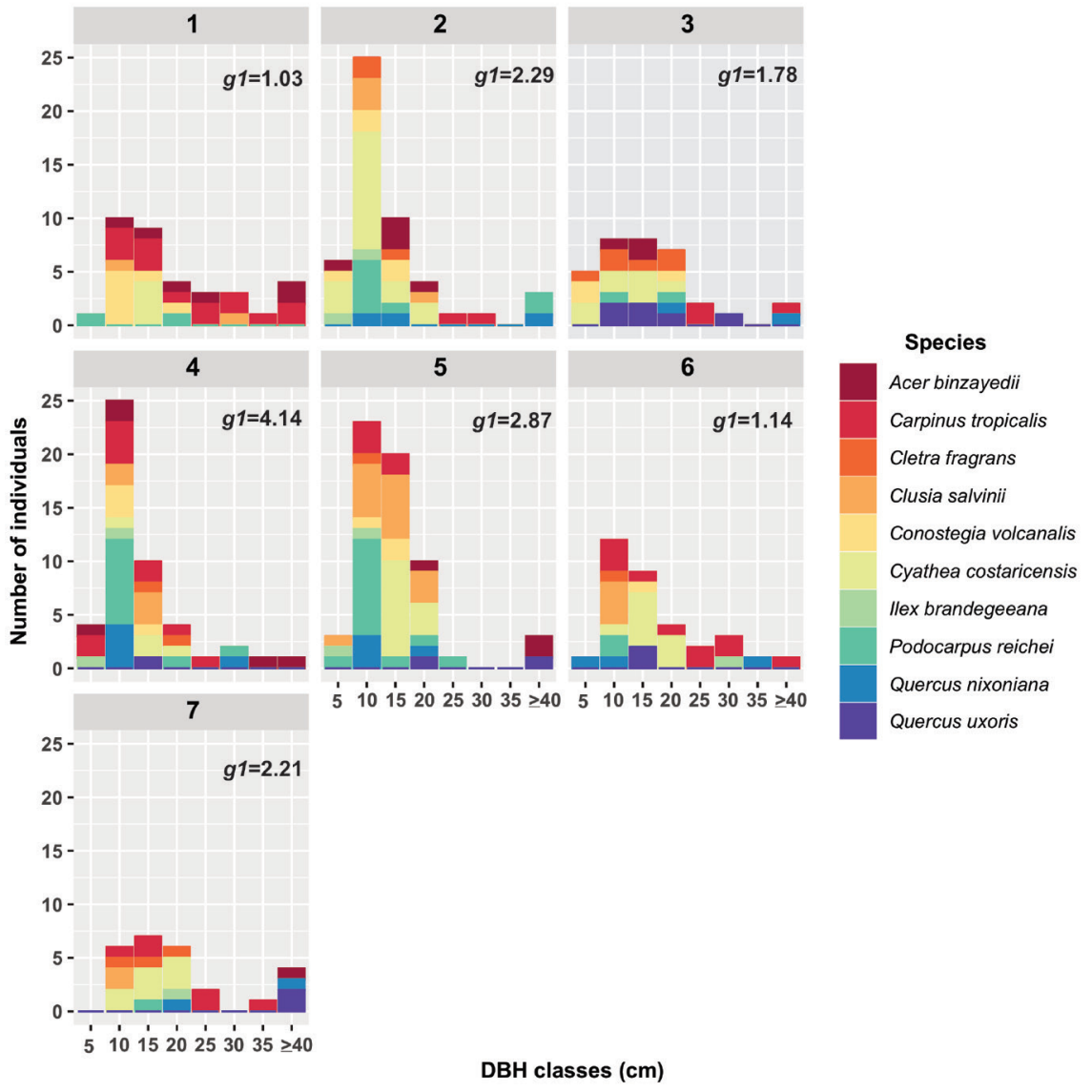

Fig. 4. Diameter at Breast Height (DBH) class frequency distribution by plot considering the ten species with Importance Index Values $>70 \% . g 1=$ coefficient of skewness.

DBH frequency distribution was not normally distributed $(\mathrm{P}<0.0001)$.

Results of the comparison using the kernel probability density function, exposed that both density-plots coincided in DBH $<25 \mathrm{~cm}$. $C$. costaricensis probability was nearly 0.1 and for the rest of the species $<0.075$. For DBH $>25$ $\mathrm{cm}$, the rest of the most important species (IVI $>70 \%$ ) presented irregular probabilities with values under 0.025 (Fig. 5D). The results of the Wilcoxon rank sum test showed no statistically significant differences in DBH between C. costaricensis population and the canopy-dominant species $(\mathrm{W}=6954, \mathrm{P}<0.8511)$.

Environmental characterization: The environment surrounding the cloud forest where C. costaricensis population occurs, showed important differences among plots, mainly in physiographic and light variables (Table 4). Elevation ranged from 1663 to 1 745 ; slope percentages ranged from 0 to $39 \%$, with high variation according to confidence intervals $(16.75 \pm 12)$. We did not observe differences in topography; hence all the plots were established over uneven terrains located on the base of slope terrains (Table 4). For rocks and stones, the mode was 0 , representing absence of these materials on the forest floor; for canopy strata, three vertical strata characterized most of the plots according to the mode value; nonetheless four canopy strata were observed in two plots (Table 4). In the case of light variables, our results showed slight dissimilarities among 


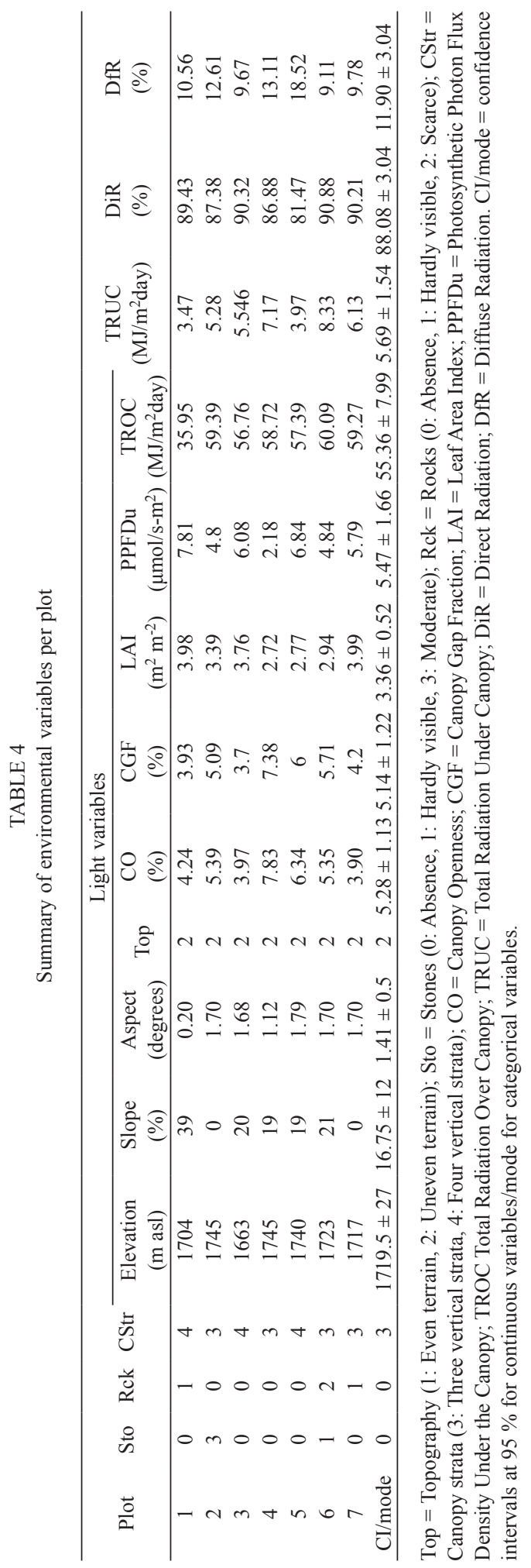

plots (Table 4). Canopy openness ranged from 3.97 to $7.83 \%$, extending only $1.13 \%$ from the mean $(5.28 \%)$, leaf area index ranged from 2.72 to $3.99\left(\mathrm{~m}^{2} \mathrm{~m}^{-2}\right)$, Photosynthetic Photon Flux Density and Total Radiation Over Canopy values ranged from 2.18 to $7.81\left(\mu \mathrm{mol} / \mathrm{s}-\mathrm{m}^{2}\right)$ and from 35.95 to $60.09\left(\mathrm{MJ} / \mathrm{m}^{2}\right.$ day) respectively (Table 4).

\section{DISCUSSION}

Floristic composition characterization: The canopy species composition associated to C. costaricensis in our study area was represented by the typical cloud forests reported for Mexico; this vegetation type is characterized by a high number of species and high structural complexity (Carvajal-Hernández et al., 2018; Rosas Rangel et al., 2019). Our results showed a combination of very abundant (Carpinus tropicalis) with sparse species (Magnolia pacifica A. Vázquez, Quercus laurina Bonpl.) in all the plots. We also found a number of species with low number of individuals (Eugenia culminicola McVaugh, Saurauia serrata DC, Myrsine coriacea (Sw.) R. Br. ex Roem. \& Schult.), which is a common feature of highly diverse cloud forests in Western Mexico (MoralesArias et al., 2018). The remnant forest in our study area is particularly diverse, characterized by species typical of cloud forests of such as: Carpinus tropicalis Magnolia pacifica, Matudaea trinervia Lundell, Podocarpus reichei, Ostrya virginiana (Mill.) K. Koch, Abies guatemalensis subsp. jaliscana (Martínez) Silba and Zinowiewia concinna Lundell (VargasRodríguez et al., 2012). This vegetation type has been present in our study area with a relatively similar species composition assembly since $1230 \mathrm{AD}$, dominated in the canopy by Acer-Podocarpus-Abies with Cyathea population in the understory; cyclical environmental changes had maintained this relict community over the last millennium (Del Castillo-Batista et al., 2016).

Community and population structural characterization: Our structural analysis 
A
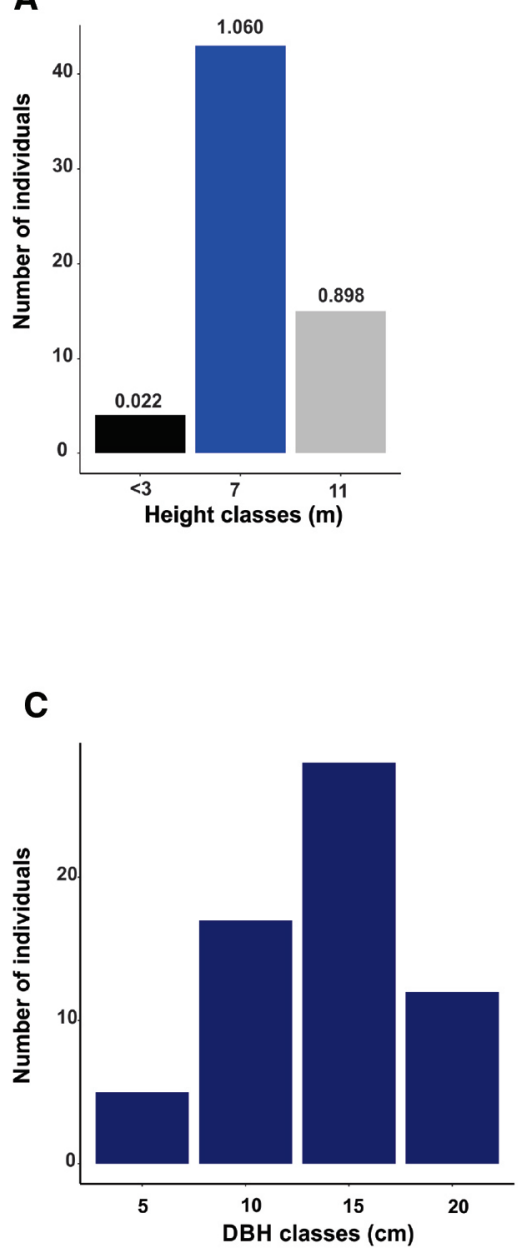
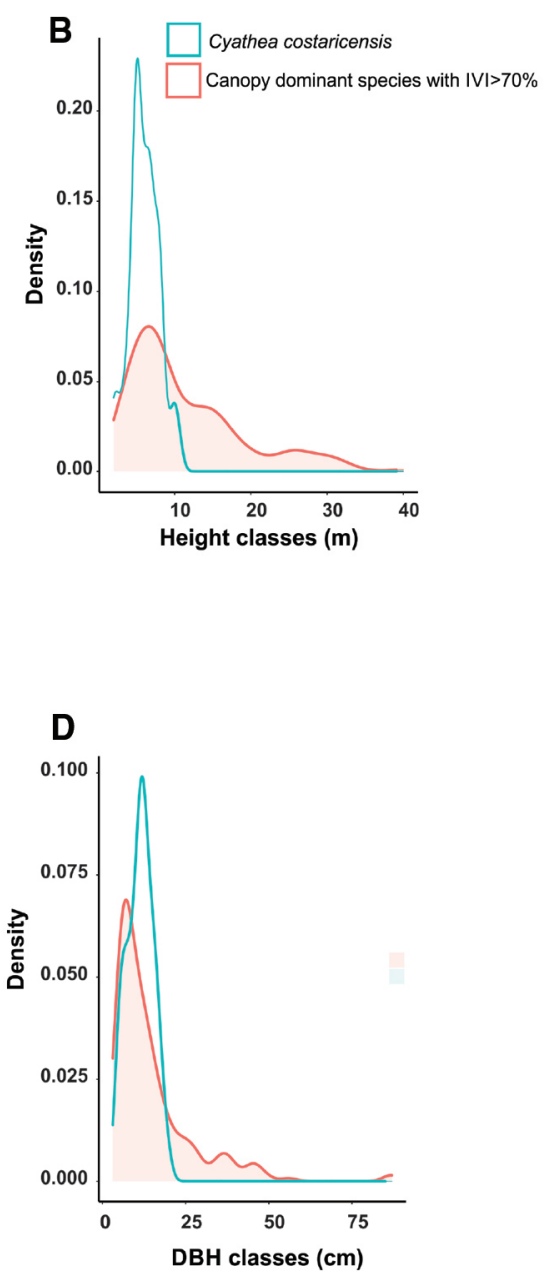

Fig. 5. A. Height class frequency distribution for Cyathea costaricensis population, B. Kernel probability density plot for height for Cyathea costaricensis (blue line) and the canopy-dominant species with IVI $>70 \%$ (red line), C. DBH class frequency distribution for Cyathea costaricensis population, D. Kernel probability density plot for DBH for Cyathea costaricensis (blue line) and the canopy-dominant species with IVI $>70 \%$ (red line).

results suggested that most of the plots displayed a DBH distribution resembling a reverse $J$-shaped curve (de Liocourt, 1898; Meyer, 1952), declining monotonically as DBH increased. Ecologically, this curve is explained by equal mortality rates among diameter classes across the entire range of diameters (Westphal et al., 2006), but this curve is also a common DBH pattern showed by tropical and cloud old-growth forests of shade-tolerant species (Rzedowski, 1978; Whitmore, 1998). In contrast, DBH distribution including only C. costaricensis population, showed a bellshape resembling a normal distribution, a result which was tested by the Shapiro-Wilks test; in contrast, trunk height was not normal according to the test, even when the symmetry of the curve was positive showing an approximation to the bell-shape distribution. Therefore, we could not confirm the hypothesis posed in this 
research where we assumed that C. costaricensis will follow a reversed $J$-shape in terms of DBH and height sizes.

Dynamic populations, which can be characterized by a bell-shape, have been reported for several tree ferns: Dicksonia sellowiana (Schmitt et al., 2009), Alsophila firma (Mehltreter \& García-Franco, 2008) Cyathea fulva (Pérez-Paredes et al., 2014) and $C$. henryi (Baker) Copel. (Balkrishna et al., 2020). A dynamic population behavior is generally attributed to a continuous regeneration pattern with good recruitment along time (Schmitt \& Windisch, 2007), together with cycles of recruitment during successive episodes of canopy gap formation (Arens, 2001). However, an opposite trunk height pattern is also common in several tree ferns: for Alsophila spinulosa (Wall. ex Hook.) R.M. Tryon, located on the Eastern coast of Japan, Nagano and Suzuki (2007) reported a $J$-shaped trunk height frequency distribution, with the number of individuals gradually decreasing as the height increased. A similar pattern was reported for Cyathea brunoniana (Wall. ex Hook.) C.B. Clarke \& Baker and $C$. henryi in Northeast India, but considering the diameter size (Balkrishna et al., 2020). This pattern of distribution is indicative of a stable population structure with a successful natural seedlings-saplings-adults replacement (Balkrishna et al., 2020). Habitat quality and anthropogenic impacts are significant factors determining the population size of tree ferns (Praptosuwiryo, 2011). Mehltreter and GarcíaFranco (2008) reported a low frequency of individuals in the smallest height size classes in Alsophila firma, in Veracruz Mexico, linked to a constraint of micro-sites and to anthropogenic disturbances hindering a successful regeneration establishment or the lack thereof, as some light-demanding tree fern species (e.g. Cyathea medullaris (G. Forst.) Sw.) prefer disturbances to regenerate and for their establishment (Bystriakova et al., 2011).

In the present study, the low number of individuals of $C$. costaricensis in the $<3 \mathrm{~m}$ height class could be explained by: 1) the potential failure of tree fern natural regeneration due to the paucity of available micro-sites; tree ferns recruitment success may be determined by habitat suitability to a larger degree, rather than their subsequent survival (Jones et al., 2007); 2) the impact of frequent forest fires, uncontrolled grazing and frequent tourist visitation (personal observations), could have negative impacts, not only in the $C$. costaricensis population structure, but also in the structure of the co-occurring canopy-dominant species, as it was previously discussed. Cyathea costaricensis in our study area is not involved in silvicultural activities; nevertheless, they are collected for ornamental uses, mainly through the direct cutting of their saplings. In the Philippines, tree ferns are extracted for commercial and medicinal purposes and even for household utility (Dadang et al., 2020). As a result of the constant tree fern "harvesting", their populations are gradually declining; these practices are contributing to a restricted populations distribution, mainly due to habitat loss and overexploitation (Kholia \& Joshi, 2010). This overexploitation is plausible to be taking place in our study area, no in an intensive manner but commonly individual by individual by tourist visitations, this could explain why population size of $C$. costaricensis in our study area is small and even fragmented. A number of tree ferns, mainly of the Cyatheaceae family (e.g. Cyathea srilankensis Ranil, C. sledgei Ranil, Pushpak. \& Fraser-Jenk, C. sinuata Hook. \& Grev., and C. hookeri Thwaites) are area-specific and they are usually confined to a few localities; as a consequence of such areaspecific requirements, their population sizes are frequently small (Ranil et al., 2017).

The typical reversed $J$-shaped was not observed for DBH or trunk height when plotting C. costaricensis population alone; however, the comparison of the kernel probability density function of $C$. costaricensis with the most important canopy-dominant species, exposed the shade tolerant behavior of this tree fern; the evidence is suggested as most of the canopy-dominant species of the remnant cloud forest in West-central Mexico were taller than C. costaricensis and by the fact they occupy 
the highest canopy strata; a high probability of occurrence was associated with tree ferns smaller than $11 \mathrm{~m}$ tall which consistently inhabit the lower strata in the study area. This structure is probably enabling the understory colonization by $C$. costaricensis individuals due to the recognized shade-tolerant behavior reported for some Cyathea species (Bystriakova et al., 2011). This result was also corroborated by the Wilcoxon non-parametric test which showed statistically significant differences for height between $C$. costaricensis individuals and the canopy-dominant species, confirming the hypotheses established in this study.

The environment surrounding Cyathea costaricensis: Interesting results emerged on the assessment of the environment where $C$. costaricensis grows: concerning the physiographical variables, we found individuals of this species growing in dissimilar percentages of slope terrain inclination and aspect orientation, but this mostly occurred on uneven terrains located at the base of the slope inclination. Studies undertaken on tree fern ecology have revealed that habitat specialization is crucial for their occurrence; particularly the results reported by Jones et al. (2007) on four species of tree ferns of the Cyatheaceae family; these authors unveiled the importance of soil chemical variables for tree fern growth, followed by their position on the slope terrain inclination and stand structural characteristics; they reported tree fern individuals growing at lower topographical positions such as riparian areas and stream valleys, similar to the location where C. costaricensis was observed to grow in our study. With respect to light variables, C. costaricensis was present in relatively similar light values across the seven plots. But we did not observe a pattern in which high values percentages of Canopy openness were associated to a high or a low number of tree fern individuals or were associated to big or small DBH and height size; however, mean canopy openness values in our study plots resemble those reported (1.07-4.05\%) for other Cyatheaceae (Cyathea medullaris; a synonymous of Sphaeropteris medullaris (G. Forst.) Bennh. and C. dealbata (G. Forst.) Sw.) species in New Zealand (Brock et al. 2019). Total Radiation Under Canopy values in this study $\left(5.69 \pm 1.54 \mathrm{MJ} / \mathrm{m}^{2}\right.$ day $)$ was also similar to the values ( 5.8 to $6.5 \mathrm{MJ} / \mathrm{m}^{2}$ day) reported in that study.

Conclusions: The structure of canopydominant species and the $C$. costaricensis population differed in height and DBH class distribution. We verify the hypothesis of similar structure between the canopy-dominant species and the $C$. costaricensis population only for $\mathrm{DBH}$; in the horizontal stratum, $C$. costaricensis is coexisting with shade-tolerant species of the remnant cloud forest showing similar sizes in $\mathrm{DBH}<25 \mathrm{~cm}$. On the contrary, there were statistical significant differences for trunk heights, the small statures of $C$. costaricensis allow their coexistence in the understory through the sheltering from the taller canopy-dominants.

Furthermore, the disjunct distribution in this relict forest, along the rather small population requires an appeal for its strict protection. Most, if not all individuals of $C$. costaricensis are confined to local environmental conditions, particularly to physiography. During our fieldwork we did not find any individuals of this species over fully open forest canopy gaps. Thus, habitat specialization, as it has been reported for a number of tree ferns elsewhere, could be the reason to explain why the $C$. costaricensis population size in our study area is small. The results of this paper are valuable for the conservation of this relict forest, in particular for Cyathea costaricensis tree fern population. Hence, conservation (e.g. protection against illegal harvesting, control of human visitation, protection against frequent uncontrolled forest fires, etc.) and management (e.g. build a forest management program for the area) strategies should be implemented in view of the limited area occupied by $C$. costaricensis and the constantly increasing levels of human-induced disturbances such as frequent forest fires, uncontrolled recreation visitation and the impact of climate change. 
Ethical statement: authors declare that they all agree with this publication and made significant contributions; that there is no conflict of interest of any kind; and that we followed all pertinent ethical and legal procedures and requirements. All financial sources are fully and clearly stated in the acknowledgements section. A signed document has been filed in the journal archives.

\section{ACKNOWLEDGMENTS}

We thank to José Guadalupe Arias Morales and Maxy Adrian Hernández Araiza for their valuable help during the fieldwork; José Guadalupe also helped us to identify the most of species. We also thank the Editors and three anonymous reviewers for their valuable comments and suggestions which substantially improved the first version of this paper.

\section{RESUMEN}

\section{Composición florística, estructura y caracterización ambiental de una población de Cyathea costaricensis en un relicto de bosque mesófilo de montaña en México}

Introducción: Los helechos arborescentes son componentes importantes de los bosques templados, tropicales y subtropicales, que contribuyen a dar forma a rodales de estructuras complejas.

Objetivos: 1) Describir la estructura poblacional de Cyathea costaricensis en un remanente de bosque nuboso del centro-oeste de México; 2) Caracterizar y relacionar la composición florística y la estructura de las especies arbóreas más importantes asociadas a la población de $C$. costaricensis y; 3) Describir el ambiente donde se encuentra C. costaricensis.

Métodos: Estimamos el Índice de Valor de Importancia (IVI) para seleccionar las especies dominantes más importantes del dosel asociadas a C. costaricensis; para las especies seleccionadas según IVI, construimos distribuciones de frecuencia de alturas y diámetros a la altura del pecho (DAP), así como para la población de C. costaricensis. Calculamos la asimetría de las distribuciones de frecuencia a través del coeficiente de asimetría y la función de densidad de probabilidad mediante la estimación de densidad de Kernel. Probamos las diferencias entre las especies de árboles dominantes en el dosel y la estructura de la población de C. costaricensis mediante la prueba no paramétrica de suma de rangos de Wilcoxon.
Resultados: los individuos de C. costaricensis presentaron las menores alturas y tamaños intermedios de DAP en comparación con las especies dominantes del dosel, con diferencias estadísticamente significativas para la altura, pero no para el DAP según la prueba de Wilcoxon. La mayoría de los individuos de helechos arborescentes se ubicaron en terrenos irregulares y sobre la pendiente baja del terreno. Los valores de apertura del dosel y Radiación total bajo el dosel fueron similares a los reportados para las especies de Cyathea en otros lugares.

Conclusiones: Confirmamos la hipótesis de que hay una estructura similar entre las especies dominantes del dosel y la población de $C$. costaricensis solo para el DAP; por el contrario, para la altura del fuste, hubo diferencias estadísticamente significativas; las pequeñas alturas de $C$. costaricensis sugieren su coexistencia en el sotobosque a través de la cobertura árboles dominantes del dosel. La mayoría de los individuos de $C$. costaricensis fueron encontrados confinados a condiciones ambientales locales, en particular a la fisiografía.

Palabras clave: helechos arborescentes; estructura poblacional; composición de especies del dosel; forma de J invertida; categorías de altura; ambiente local.

\section{REFERENCES}

Arens, N. C. (2001). Variation in performance of the tree fern Cyathea caracasana (Cyatheaceae) across a successional mosaic in an Andean cloud forest. American Journal of Botany, 88(3), 545-551. https://doi. org/10.2307/2657118

Balkrishna, A., Arya, V., \& Kushwaha, A. K. (2020). Population structure, regeneration status and conservation measures of threatened Cyathea spp. Journal of Tropical Forest Science, 32(4), 414-421. https://doi. org/10.26525/jtfs2020.32.4.414

Beers, T., Dress, P., \& Wensel, L. (1966). Notes and Observations: Aspect Transformation in Site Productivity Research. Journal of Forestry, 64(10), 691-692. https://doi.org/10.1093/jof/64.10.691

Bernabe, N., Williams-Linera, G., \& Palacios-Rios, M. (1999). Tree Ferns in the Interior and at the Edge of a Mexican Cloud Forest Remnant: Spore Germination and Sporophyte Survival and Establishment. Biotropica, 31(1), 83-88. https://doi.org/10.2307/2663961

Brock, J. M. R., Burns, B. R., Perry, G. L. W., \& Lee, W. G. (2019). Gametophyte niche differences among sympatric tree ferns. Biology Letters, 15(1). https:// doi.org/10.1098/rsbl.2018.0659

Brock, J. M. R., Morales, N. S., Burns, B. R., \& Perry, G. L. W. (2020). The hare, tortoise and crocodile revisited: Tree fern facilitation of conifer persistence and angiosperm growth in simulated forests. 
Journal of Ecology, 108(3), 969-981. https://doi. org/10.1111/1365-2745.13305

Brock, J. M. R., Perry, G. L. W., Burkhardt, T., \& Burns, B. R. (2018a). Forest seedling community response to understorey filtering by tree ferns. Journal of Vegetation Science, 29(5), 887-897. https://doi.org/10.1111/ jvs. 12671

Brock, J. M. R., Perry, G. L. W., Lee, W. G., Schwendenmann, L., \& Burns, B. R. (2018b). Pioneer tree ferns influence community assembly in northern New Zealand forests. New Zealand Journal of Ecology, 42(1), 18-30. https://doi.org/10.20417/nzjecol.42.5

Bystriakova, N., Bader, M., \& Coomes, D. A. (2011). Long-term tree fern dynamics linked to disturbance and shade tolerance. Journal of Vegetation Science, 22(1), 72-84. https://doi. org/10.1111/j.1654-1103.2010.01227.x

Carvajal-Hernández, C. I., Gómez-Díaz, J. A., Kessler, M., \& Krömer, T. (2018). Influence of elevation and habitat disturbance on the functional diversity of ferns and lycophytes. Plant Ecology and Diversity, 11(3), 335-347. https://doi.org/10.1080/17550874.2 018.1484526

Chacón-Labella, J., De la Cruz, M., Vicuña, R., Tapia, K., \& Escudero, A. (2014). Negative density dependence and environmental heterogeneity effects on tree ferns across succession in a tropical montane forest. Perspectives in Plant Ecology, Evolution and Systematics, 16(2), 52-63. https://doi.org/10.1016/j. ppees.2014.02.003

Dadang, R. J., Casinillo, N. G. B., Coritico, F. P., Simborio, L. T., \& Amoroso, V. B. (2020). Living with endangered species: Collection of tree ferns in the forest-reserve of Marilog district, Southern Philippines. Trees, Forests and People, 2, 100041. https://doi. org/10.1016/j.tfp.2020.100041

de Liocourt, F. (1898). De l'aménagement des sapinières. Bulletin Société forestière de Franche-Comté \& Belfort, 4(6), 396-409.

Del Castillo-Batista, A. P., Figueroa-Rangel, B. L., LozanoGarcía, S., Olvera-Vargas, M., \& Cuevas-Guzmán, R. (2018). 1580 years of human impact and climate change on the dynamics of a Pinus-Quercus-Abies forest in west-central Mexico. Revista Mexicana de Biodiversidad, 89, 208-225. https://doi.org/10.22201/ ib.20078706e.2018.1.2117

Del Castillo-Batista, A. P., Figueroa-Rangel, B. L., LozanoGarcía, S., Olvera-Vargas, M., \& Guzmán, R. C. (2016). Floristic and environmental history of the cloud forest in west-central Mexico during the little ice age. Revista Mexicana de Biodiversidad, 87(1), 216-229. https://doi.org/10.1016/j.rmb.2016.01.021
Etherington, J. R., Moore, P. D., \& Chapman, S. B. (1987). Methods in Plant Ecology. The Journal of Ecology, 75(1), 283-284. https://doi.org/10.2307/2260556

Fedrigo, M., Stewart, S. B., Kasel, S., Levchenko, V., Trouvé, R., \& Nitschke, C. R. (2019). Radiocarbon Dating Informs Tree Fern Population Dynamics and Disturbance History of Temperate Forests in Southeast Australia. Radiocarbon, 61(2), 445-460. https://doi. org/10.1017/RDC.2018.119

Forbes, A. S., Norton, D. A., \& Carswell, F. E. (2016). Tree fern competition reduces indigenous forest tree seedling growth within exotic Pinus radiata plantations. Forest Ecology and Management, 359, 1-10. https:// doi.org/10.1016/j.foreco.2015.09.036

Gaxiola, A., Burrows, L. E., \& Coomes, D. A. (2008). Tree fern trunks facilitate seedling regeneration in a productive lowland temperate rain forest. Oecologia, 155(2), 325-335. https://doi.org/10.1007/ s00442-007-0915-8

Hernández-Álvarez, A. G., Sánchez-González, A., \& Tejero-Díez, J. D. (2019). Licofitas y helechos del bosque mesófilo de montaña del estado de Hidalgo, México. Botanical Sciences, 97(2), 236-249. https://doi. org/10.17129/botsci.2093

Jones, M. M., Olivas Rojas, P., Tuomisto, H., \& Clark, D. B. (2007). Environmental and neighbourhood effects on tree fern distributions in a neotropical lowland rain forest. Journal of Vegetation Science, 18(1), 13-24. https://doi.org/10.1111/j.1654-1103.2007.tb02511.x

Kholia, B. S., \& Joshi, R. (2010). International Year of Biodiversity - Adopting innovative measures for conservation. NeBIO, 1(2), 55-61.

MacFarland, T. W., \& Yates, J. M. (2016). Introduction to Nonparametric Statistics for the Biological Sciences Using $R$. Springer. https://doi. org/10.1007/978-3-319-30634-6

Mehltreter, K., \& GarcÍa-Franco, J. G. (2008). Leaf Phenology and Trunk Growth of the Deciduous Tree Fern Alsophila firma (Baker) D. S. Conant in a Lower Montane Mexican Forest. American Fern Journal, 98(1), 1-13. https://doi. org/10.1640/0002-8444(2008)98[1:lpatgo]2.0.co;2

Mendoza-Ruiz, A., \& Ceja-Romero, J. (2014). Atlas de briofitas y pteridofitas. Universidad Autónoma Metropolitana, Mexico.

Meyer, H. A. (1952). Balanced Growth and Drain in Uneven-Aged Forests. Journal of Forestry, 50, 85-92.

Mickel, J. T., \& Smith, A. R. (2004). The Pteridophytes of Mexico. Part I (Descriptions and Maps). The New York Botanical Garden.

Morales-Arias, J. G., Olvera-Vargas, M., Cuevas-Guzmán, R., Figueroa-Rangel, B. L., \& Sánchez-Rodríguez, 
E. V. (2018). Environmental variation and floristic composition of tree species in a humid mountain forest in western Mexico. Revista Mexicana de Biodiversidad, 89(3), 769-783. https://doi.org/10.22201/ ib.20078706e.2018.3.2456

Nagano, T., \& Suzuki, E. (2007). Leaf demography and growth pattern of the tree fern Cyathea spinulosa in Yakushima Island. Tropics, 16(1), 47-57. https://doi. org/10.3759/tropics. 16.47

Negrão, R., Sampaio-e-Silva, T., Kortz, A. R., Magurran, A., \& Silva Matos, D. M. (2017). An endangered tree fern increases beta-diversity at a fine scale in the Atlantic Forest Ecosystem. Flora: Morphology, Distribution, Functional Ecology of Plants, 234, 1-6. https://doi.org/10.1016/j.flora.2017.05.020

Olvera-Vargas, M., Moreno-Gómez, S., \& Figueroa-Rangel, B. L. (1996). Sitios permanentes para la investigación silvícola: Manual para su establecimiento. Universidad de Guadalajara, México.

Pérez-Paredes, M. G., Sánchez-González, A., \& TejeroDíez, J. D. (2014). Estructura poblacional y características del hábitat de dos especies de Cyatheaceae del estado de Hidalgo, México. Botanical Sciences, 92(2), 259-271. https://doi.org/10.17129/botsci.48

Praptosuwiryo, T. N. (2011). Inventorying of the tree fern Genus Cibotium of Sumatra: Ecology, population size and distribution in North Sumatra. Biodiversitas, Journal of Biological Diversity, 12(4), 204-211. https://doi.org/10.13057/biodiv/d120404

Ramírez-Barahona, S., Luna-Vega, I., \& Tejero-Díez, D. (2011). Species richness, endemism, and conservation of American tree ferns (Cyatheales). Biodiversity and Conservation, 20(1), 59-72. https://doi. org/10.1007/s10531-010-9946-2

Ranil, R. H. G., Pushpakumara, D. K. N. G., Wijesundara, D. S. A., Bostock, P. D., Ebihara, A., \& FraserJenkins, C. R. (2017). Diversity and distributional ecology of tree ferns of Sri Lanka: A step towards conservation of a unique gene pool. Ceylon Journal of Science, 46(5), 127-135. https://doi.org/10.4038/ cjs.v46i5.7460

Regent Instruments Inc. (2005). WinSCANOPY for hemispherical image analysis. [Software]. Regents Instruments Inc. https://regentinstruments.com/assets/ winscanopy_mostrecent.html

Rosas Rangel, D. M., Mendoza, M. E., Gómez-Tagle, A., \& Marín, C. T. (2019). Advances and challenges in the knowledge on the tropical mountain cloud forests of Mexico. Madera y Bosques, 25(1), e2511759. https:// doi.org/10.21829/myb.2019.2511759

Ruiz Coyoahua, C. F. (2020). Distribución y estado de conservación de helechos arborecentes (Cyatheaceae) del estado de Veracruz, México. Universidad Veracruzana, México.
Rzedowski, J. (1978). La vegetación de México. Editorial Limusa.

Schmitt, J. L., Schneider, P. H., \& Windisch, P. G. (2009). Crescimento do cáudice e fenologia de Dicksonia sellowiana Hook. (Dicksoniaceae) no sul do Brasil. Acta Botanica Brasilica, 23(1), 282-291. https://doi. org/10.1590/s0102-33062009000100030

Schmitt, J. L., \& Windisch, P. G. (2007). Estrutura populacional e desenvolvimento da fase esporofítica de Cyathea delgadii Sternb. (Cyatheaceae, Monilophyta) no sul do Brasil. Acta Botanica Brasilica, 21(3), 731-740. https://doi.org/10.1590/ s0102-33062007000300019

Secretaría del Medio Ambiente y Recursos Naturales. (2010). Norma Oficial Mexicana NOM-059-SEMARNAT-2010. Protección ambiental-Especies nativas de México de flora y fauna silvestres-Categorías de riesgo y especificaciones para su inclusión, exclusión o cambio-Lista de especies en riesgo. Diario Oficial de la Federación, México.

Shepherd, L. D., Brownsey, P. J., Stowe, C., Newell, C., \& Perrie, L. R. (2019). Genetic and morphological identification of a recurrent Dicksonia tree fern hybrid in New Zealand. PLOS ONE, 14(5), e0216903. https:// doi.org/10.1371/journal.pone.0216903

R Core Team. (2018). $R$ : A language and environment for statistical computing. $\mathrm{R}$ foundation for Statistical Computing, Viena, Austria. http//www.R-project.org

Tropicos.org. (2021). Tropicos.org. Missouri Botanical Garden. Recuperado el 20 de Agosto de 2021, de https://tropicos.org

Vargas-Rodríguez, Y. L., Vázquez-García, J. A., Quintero Moro, T., Muñiz-Castro, M., Shalisko, V., GarcíaJiménez, C. I., Fernández, J., De Fuentes, K., \& Lanoue, C. (2012). Propuesta para la protección del bosque mesófilo con arce (Jalisco, México), bajo la categoría de parque estatal. En E. Salcedo Pérez, E. Hernández Álvarez, J. A. Vázquez-García, T. EscotoGarcía, N. Díaz Echavarría (Eds.), Recursos Forestales del Occidente de México: Diversidad, Manejo, Producción, Aprovechamiento y Conservación (pp. 510-553). Universidad de Guadalajara, México.

Vázquez-García, J. A., Vargas-Rodríguez, Y. L., \& Aragón Cruz, F. (2000). Descubrimiento de un bosque de Acer-Podocarpus-Abies en el municipio de Talpa de Allende, Jalisco, México. Boletín del Instituto de Botánica de la Universidad de Guadalajara, 7, 159-183.

Villaseñor, J. L. (2010). El bosque húmedo de montaña en México y sus plantas vasculares: catálogo florísticotaxonómico. Comisión Nacional para el Conocimiento y Uso de la Biodiversidad - Universidad Nacional Autónoma de México. 
Weglarczyk, S. (2018). Kernel density estimation and its application. ITM Web of Conferences, 23, 00037. https://doi.org/10.1051/itmconf/20182300037

Westphal, C., Tremer, N., von Oheimb, G., Hansen, J., von Gadow, K., \& Härdtle, W. (2006). Is the reverse J-shaped diameter distribution universally applicable in European virgin beech forests? Forest Ecology and Management, 223(1-3), 75-83. https://doi. org/10.1016/j.foreco.2005.10.057

Whitmore, T. C. (1998). An Introduction to Tropical Rain Forests. Oxford University Press.
Wright, S. J., Muller-Landau, H. C., Condit, R., \& Hubbell, S. P. (2003). Gap-dependent recruitment, realized vital rates, and size distributions of tropical trees. Ecology, 84(12), 3174-3185. https://doi. org/10.1890/02-0038

Zhang, Y., Chen, J. M., \& Miller, J. R. (2005). Determining digital hemispherical photograph exposure for leaf area index estimation. Agricultural and Forest Meteorology, 133(1-4), 166-181. https://doi. org/10.1016/j.agrformet.2005.09.009 